\title{
Gender differences in academic achievement: A matter of contextual classroom influence?
}

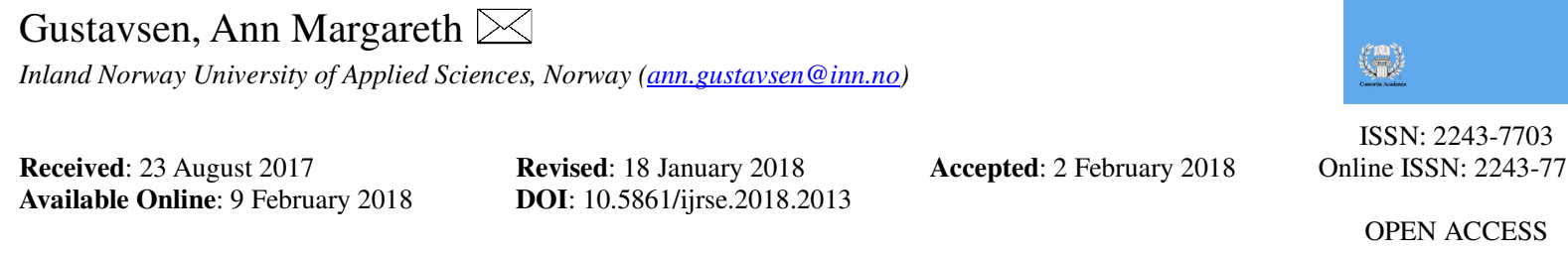

ISSN: $2243-7703$

Accepted: 2 February 2018

OPEN ACCESS

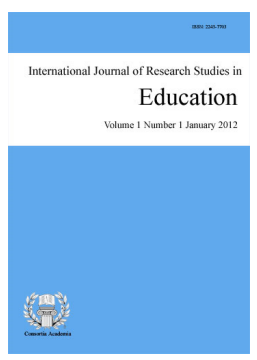

\section{Abstract}

The main aim of this study was to investigate the extent to which prior social skills and academic achievement as well as the teachers' gender and the gender ratio of classes explained boys' and girls' teacher-assessed academic achievement in Norwegian, mathematics and English. Data were collected from 153 classes at 27 Norwegian schools in the autumn of 2012 and 2014, including 2,266 first to tenth grade students, and were controlled for age, cultural background, prior social skills and prior academic achievement at the individual level and for class size. Overall, the results showed that previous academic achievement at the classroom level explained variance in boys' and girls' individual academic achievements in English and mathematics. In Norwegian, only the previous academic achievement at a class level was explanatory for girls subsequent individual achievement. The effects of previous academic achievement seemed to be larger for girls than for boys. Gender of teacher seemed to explain some of the variance for girls' academic achievement in Norwegian and English, but not for boys. In addition, at the classroom level, social skills and the gender ratio did not significantly influence boys' and girls' academic achievement.

Keywords: gender differences; academic achievement; social skills; multilevel analysis; classroom environment 


\section{Gender differences in academic achievement: A matter of contextual classroom influence?}

\section{Introduction}

One of the main challenges for schools is to optimise the learning and teaching environment in order to enable students to achieve their maximum potential and to prevent dropouts (Hendriks, Kuyper, Lubbers, \& Van der Werf, 2011). Many studies have shown that, on average, girls perform better in school than boys, both academically (Backe-Hansen, Walhovd, \& Huang, 2014; Legewie \& DiPrete, 2012; Lekholm \& Cliffordson, 2009; OECD, 2015; Spinath, Eckert, \& Steinmayr, 2014; Vantieghem \& Van Houtte, 2015; Voyer \& Voyer, 2014) and socially (Jurado, Cumba-Aviles, Collazo, \& Matos, 2006; Kjøbli \& Ogden, 2009). At schools and in the classroom, children are expected to assert themselves academically through interacting socially with teachers and peers and through mastering specific areas of interest (Wentzel, 2015). In this respect, children must develop strong academic and social skills to be successful at school. A substantial body of literature has documented a predictive relationship between teacher-rated social skills and long-term academic achievement (Caemmerer \& Keith, 2015; Caprara, Barbaranelli, Pastorelli, Bandura, \& Zimbardo, 2000; Konold, Jamison, Stanton-Chapman, \& Rimm-Kaufman, 2010; Malecki \& Elliott, 2002; Wentzel, 1991, 1993).

Teachers assess students' cognitive and social development on a daily basis during instruction, interactions and assessments (Retelsdorf, Schwartz, \& Asbrock, 2014). Their perceptions of a classroom situation or of a student's ability and behaviour is often influenced by context, such as class composition, beliefs, earlier experiences and the aims of a task or activity (Kikas, Silinskas, \& Soodla, 2015). Teachers' perceptions may also be based on the individual characteristics of a student, such as his or her gender, ethnicity, socio-economic background and attractiveness, which are independent of a student's academic ability (Hansen, 2016). This can create some challenges for fair assessment given that teachers must grade students within the educational system (Baker, Tichovolsky, Kupersmidt, Voegler-Lee, \& Arnold, 2015).

Previously, researchers often have investigated gender differences in academic achievement at the individual level, such as socioeconomic/ethnic background, without focusing on different contextual influences in schools (Legewie \& DiPrete, 2012). However, classrooms are dynamic, complex social systems with unique processes (reciprocal interactions), persons (unique attributes and skills) and contexts (environmental influences) that influence the development of students (Bronfenbrenner \& Morris, 2006). Children often behave differently in different contexts and classrooms (Kaplan, Gheen, \& Midgley, 2002). To investigate students' academic achievement, researchers should therefore consider both individual and contextual levels. An ecological approach can provide a framework for understanding multiple levels of influence on boys' and girls' academic achievement. From this perspective, child development is influenced by the interaction between children's individual characteristics and their environments (e.g. the classroom) (Bronfenbrenner, 1989), wherein some influential factors operate at the classroom or school level and some at the student level (Patrick, Kaplan, \& Ryan, 2011).

The present study aims to contribute to previous research and knowledge by conducting a detailed investigation of the importance of class variables (such as social skills, academic achievement and gender ratio) on boys' and girls' teacher-assessed academic achievement in three school subjects, Norwegian, mathematics and English, over the course of two years.

\section{Contextual and individual factors influencing students' academic achievement}

At a contextual level, class composition variables such as (a) the proportion of students in a class who are female, belong to an ethnic minority or have low socioeconomic status as well as (b) the average initial cognitive 
ability level of a class, have been found to exert effects on academic achievement (De Fraine, Van Damme, Van Landeghem, Opdenakker, \& Onghena, 2003; Hendriks et al., 2011). A study of secondary education classes indicated that language achievement was higher for students who attended classes with a higher average cognitive ability or a large proportion of girls (De Fraine et al., 2003). Additionally, students' average academic achievement and sociodemographic characteristics appear to influence teacher assessments. Teachers in high-achieving and high socioeconomic status classrooms overestimated their students' literacy abilities, even after controlling for student socioeconomic status and measurable achievements and vice versa (Ready \& Wright, 2011). The number of children in each classroom may also be another important contextual characteristic.

Even so, few research studies have focused on the influence of the average social skill level of a classroom on students' academic achievement. Prior studies have shown that students may learn effective study skills as well as positive engagement and attitudes towards school by observing and imitating their high-achieving friends (Veronneau \& Dishion, 2011; Wentzel, 2005); so, it is reasonable to assume that the average social skill level of a class might influence boys' and girls' academic achievement. Previously, researchers suggested that students learn and achieve better in classrooms with positive climates (Moos, 1979; Murphy, Weil, \& McGreal, 1986) and that student behaviour levels vary among classrooms (Kaplan et al., 2002). Teachers' subjective assessments of student academic achievement are also found to vary among schools (Galloway, Kirkebøen, \& Rønning, 2011).

In the present study, 'contextual effects' as a term is defined as the significant incremental contribution of the group mean of an explanatory variable over and above its level-one (student level) predictive contribution (Snijders \& Bosker, 2012). More precisely, for this study, contextual effects are classroom aggregates of individual student characteristics (e.g. class-average achievement, class-average social skills or gender ratio) that are specific to an individual and not interchangeable with other students. In this respect, the same level 1 variable can be used to construct both level 1 and level 2 constructs (Marsh et al., 2012). Individual characteristics such as academic achievement and social skills must also be controlled for upon examining the influence of aggregated variables (e.g. the class mean of teacher-assessed social skills and academic achievement) or indexes of class composition (e.g. gender ratio) on individual outcomes (Frenzel, Pekrun, \& Goetz, 2007; Marsh et al., 2012; Morin, Marsh, Nagengast, \& Scalas, 2014).

Individual characteristics aggregated at the classroom level, such as the gender composition of a class, for example, can thus take on a different meaning when analysed as this level (Arens, Morin, \& Watermann, 2015). The referent at both levels is the individual student, and different students within the same class might have different true scores (Marsh et al., 2012). Context might also influence individuals in different ways. In any case, previous research suggests that aggregated scores are valid measures of classroom environments (De Jong \& Westerhof, 2001). The group means or average levels of different variables in a classroom can be important explanatory variables of academic achievement at the classroom level (Hendriks et al., 2011).

At the student level, previous studies indicate that grades are not merely a reflection of students' academic subject knowledge but are also influenced by other factors (Lekholm \& Cliffordson, 2008) such as social skills (Malecki \& Elliott, 2002). For example, subjective teacher grading is found to have a stronger relationship with student social skills than objective test scores (Diprete \& Jennings, 2012). Student learning behaviours explained more variation in teacher-assigned grades and student scholastic performance than intelligence (Schaefer \& McDermott, 1999). This indicates that students who better fit teachers' expectations or perceptions of good behaviour receive better grades independently of their true intellectual abilities. Several studies have suggested the presence of a bi-directional relation between social skills and achievement (Caemmerer \& Keith, 2015; Hinshaw, 1992; Miles \& Stipek, 2006). In other cases, students' achievement was shown to significantly affect their social skills and hence students' social skills was shown to significantly influence their subsequent achievements. However, these effects seemed to vary at different class levels (Caemmerer \& Keith, 2015; Miles \& Stipek, 2006). 


\subsection{Influence of gender on academic achievement}

With respect to gender, girls are more likely to receive higher ratings in social skills than boys (Gresham \& Elliott, 1990). In addition, international studies have documented large gender differences between subjective teacher assessments and objective test scores (Cornwell, Mustard, \& Parys, 2013; Lekholm \& Cliffordson, 2008). In Norway, girls receive better grades than boys in subjective teacher assessments than in exams, even though these assessments and exams evaluate the same skills, indicating that subjective teacher grading might not be favourable for boys (Falch \& Naper, 2013).

At the classroom level, one study from the Netherlands found that, in the first year of secondary education, boys who began classes with a relatively high level of Dutch showed greater Dutch achievement compared to boys who started classes with a relatively low average level of Dutch (Hendriks et al., 2011). A German study of 69 classes across grades 5-10 suggested that students in 'male-dominated' mathematics classes seemed to experience more anxiety and less enjoyment and to show more negative emotional patterns than students in classes with a higher ratio of girls (Frenzel et al., 2007). However, the results are mixed. A Norwegian study found that the proportion of boys and girls in the classroom had no significant effect on mean mathematical achievement (Manger \& Gjestad, 1997).

In recent years, the number of female teachers in compulsory school has increased and researchers have investigated to what extent gender of teacher influence assessment of boys' and girls' academic achievement (de Zeeuw et al., 2014; Sokal \& Katz, 2008). The results are mixed. Most studies did not find an influence of teachers' gender on students' academic achievement in compulsory school (Antecol, Ozbeklik, \& Eren, 2015; Burusic, Babarovic, \& Seric, 2012; Cho, 2012; de Zeeuw et al., 2014; Ehrenberg, Goldhaber, \& Brewer, 1995; Helbig, 2012; Holmlund \& Sund, 2008; Neugebauer, Helbig, \& Landmann, 2011; Sokal \& Katz, 2008). Anyway, some studies found that the variance in academic achievement (Dee, 2007; Klein, 2004) and student behavior (Dee, 2007) was due to teacher gender. Other studies did observe an influence of a same-gender teacher on academic achievements in mathematics (Ammermüller \& Dolton, 2006; Dee, 2007) and reading (Dee, 2007). An American study with more than 1.7 million students in grades three through ten found no significant relationship between teachers' gender and students' academic achievement in elementary grades, but in middle and high school grades (Winters, Haight, Swaim, \& Pickering, 2013).

A body of research has further documented the effects of teachers' perceptions of gender on academic outcomes (Baker et al., 2015; De Boer, Bosker, Van Der Werf, \& Graesser, 2010; Hinnant, O'Brien, \& Ghazarian, 2009). Teacher assessments of students' reading skills (Catsambis, Mulkey, Buttaro, Steelman, \& Koch, 2012) and mathematical skills (Tiedemann, 2002) were found to be gender stereotyped. Because of such gendered expectations, teachers may evaluate the same behaviour and social skill differently depending on a student's gender (American Association of University Women, 1992). In a US study, teachers tended to overestimate reading skills in girls and underestimate them in boys in first, third and fifth grades (Hinnant et al., 2009). Similar findings were documented in kindergarten (Ready \& Wright, 2011). In addition, a German study of thirdand fifth-grade students found that gender stereotypes influenced teachers' perceptions of remedial and low-performing students but not of high-achieving students. Furthermore, teachers also rated boys as having greater abilities in mathematics than girls (Tiedemann, 2002).

Therefore, the implications of these gender-related findings and teacher-based assessments should be interpreted cautiously. One meta-analysis suggested that greater concern should be placed on variance within groups of boys and groups of girls because variance within these groups in mathematics is larger than variance between these groups (Hyde, Fennema, Lamon, \& Appelbaum, 1990). In another meta-analysis, John Hattie ranked 138 influences that are related to learning outcomes from very positive effects to very negative effects. The study showed that the effect of gender, such as differences in psychological dimensions, communications, social and personality variables and so on, related to student achievement is weak (Hattie, 2009). 


\subsection{Research questions}

A substantial body of literature has documented the existence of a relationship between social skills and academic achievement (Caemmerer \& Keith, 2015; Konold et al., 2010; Malecki \& Elliott, 2002; Wentzel, 1991, 1993). A few studies have also explored the influence of social skills and gender in academic achievement (Duckworth \& Seligman, 2006; Weis, Heikamp, \& Trommsdorff, 2013). Even so, several gaps in knowledge remain in the literature. First, few studies have examined students' social skills at the classroom level in general. Second, most studies have defined academic achievement in terms of reading and mathematics skills, yet little research has addressed the association between classroom context variables and other school subjects, such as mother language, mathematics and second language. Third, few studies have included several class levels in their analyses. Usually, only one or two class levels are measured several times. Fourth, the influence of social skills on boys' and girls' academic achievement at the classroom level is still unknown and unaddressed in the literature (Oberle, Schonert-Reichl, Hertzman, \& Zumbo, 2014).

More knowledge on these topics is thus needed to achieve a better understanding of the nuanced effects of gender in the classroom. The present study addresses the above-mentioned gaps in the literature by seeking to answer the following question: To what extent might teacher assessments of boys' and girls' social skills and academic achievement at the classroom level, as well as the teachers' gender and the gender ratio in the classroom, explain variance in teacher assessments of students' individual academic achievements in Norwegian, mathematics and English? This question was examined after controlling for age, cultural background, prior social skills and academic achievement at the individual level and for class size.

\section{Methodology}

\subsection{Participants}

Participants included 2,266 Norwegian schoolchildren nested in 153 classes at 27 schools in 14 municipalities distributed throughout six counties. Teachers rated students from first through eighth grade at an initial measurement point (T1) and from third to tenth grade at a subsequent measurement point (T2) in order to measure the same set of students and corresponding effects at two different points in time. Of the student sample, $50.2 \%$ were girls $(n=1,138)$, and $49.8 \%$ were boys $(n=1,128)$. Female teachers completed $83 \%$ of the student ratings. The minimum number of students per class was 10 , and the maximum was 43 . The mean class size for the sample was 16.58. Table 1 shows the number of students in the various class levels and the percentages of girls and boys, including the number of classes and the mean class size of each class level.

Table 1

Participants' demographics

\begin{tabular}{|c|c|c|c|c|c|c|c|c|c|c|}
\hline \multicolumn{11}{|c|}{ Class level } \\
\hline Variables & 1 & 2 & 3 & 4 & 5 & 6 & 7 & 8 & 9 & 10 \\
\hline \multicolumn{11}{|l|}{$\mathrm{T} 1$} \\
\hline Number of students & 359 & 374 & 350 & 382 & 335 & 62 & 109 & 295 & & \\
\hline Girls & $46.2 \%$ & $50 \%$ & $50 \%$ & $52.4 \%$ & $49.6 \%$ & $56.5 \%$ & $55 \%$ & $50.5 \%$ & & \\
\hline Boys & $53.8 \%$ & $50 \%$ & $50 \%$ & $47.6 \%$ & $50.4 \%$ & $43.5 \%$ & $45 \%$ & $49.5 \%$ & & \\
\hline Number of classes & 23 & 25 & 25 & 28 & 23 & 5 & 8 & 16 & & \\
\hline \multicolumn{11}{|l|}{ Teacher ratings } \\
\hline Female & $94.4 \%$ & $99.7 \%$ & $95.4 \%$ & $86.9 \%$ & $63.7 \%$ & $100 \%$ & $63.2 \%$ & $53.6 \%$ & & \\
\hline Male & $5.6 \%$ & $0.3 \%$ & $4.6 \%$ & $13.1 \%$ & $36.3 \%$ & $0 \%$ & $36.8 \%$ & $46.4 \%$ & & \\
\hline $\begin{array}{l}\text { Mean } \\
\text { class size (SD) }\end{array}$ & $\begin{array}{l}18.61 \\
(9.65)\end{array}$ & $\begin{array}{l}18.87 \\
(7.55)\end{array}$ & $\begin{array}{l}15.21 \\
(4.88)\end{array}$ & $\begin{array}{l}14.90 \\
(5.12)\end{array}$ & $\begin{array}{l}16.73 \\
(5.36)\end{array}$ & $\begin{array}{l}12.87 \\
(2.65)\end{array}$ & $\begin{array}{l}14.14 \\
(2.61)\end{array}$ & $\begin{array}{l}19.16 \\
(5.34)\end{array}$ & & \\
\hline
\end{tabular}


Gustavsen, A. M.

Table 1 ... continued

\begin{tabular}{|c|c|c|c|c|c|c|c|c|c|c|}
\hline \multicolumn{11}{|c|}{ Class level } \\
\hline Variables & 1 & 2 & 3 & 4 & 5 & 6 & 7 & 8 & 9 & 10 \\
\hline \multicolumn{11}{|l|}{$\mathrm{T} 2$} \\
\hline Number of students & & & 359 & 374 & 350 & 382 & 335 & 62 & 109 & 295 \\
\hline Girls & & & $46.2 \%$ & $50 \%$ & $50 \%$ & $52.4 \%$ & $49.6 \%$ & $56.5 \%$ & $55 \%$ & $50.5 \%$ \\
\hline Boys & & & $53.8 \%$ & $50 \%$ & $50 \%$ & $47.6 \%$ & $50.4 \%$ & $43.5 \%$ & $45 \%$ & $49.5 \%$ \\
\hline Number of classes & & & 23 & 25 & 25 & 28 & 23 & 5 & 8 & 16 \\
\hline \multicolumn{11}{|l|}{ Teacher ratings } \\
\hline Female & & & $94.4 \%$ & $99.7 \%$ & $95.4 \%$ & $86.9 \%$ & $63.7 \%$ & $100 \%$ & $63.2 \%$ & $53.6 \%$ \\
\hline Male & & & $5.6 \%$ & $0.3 \%$ & $4.6 \%$ & $13.1 \%$ & $36.3 \%$ & $0 \%$ & $36.8 \%$ & $46.4 \%$ \\
\hline Mean & & & 18.61 & 18.87 & 15.21 & 14.90 & 16.73 & 12.87 & 14.14 & 19.16 \\
\hline class size (SD) & & & $(9.65)$ & $(7.55)$ & $(4.88)$ & $(5.12)$ & $(5.36)$ & $(2.65)$ & $(2.61)$ & $(5.34)$ \\
\hline
\end{tabular}

\subsection{Procedure}

Data were collected using an online questionnaire developed by the Centre for the Study of Educational Practice (SePU) at the Inland Norway University of Applied Sciences. Social skills and academic achievement were measured through informant-based reports provided by teachers. Teachers were also asked to share the background information, such as cultural background and gender, of students. The survey was one key element of a larger school development project, the LP model (Learning environment and Pedagogical analysis), administered by the Centre for Learning Environment (CLE) at the University of Stavanger. The LP model has been employed as part of a comprehensive programme that encompasses several municipalities, wherein the directors of schools in each municipality can decide whether or not to participate and to provide information to the CLE, which remains in constant dialogue with schools. Following the approval of the study, SePU administered the survey and gathered data in the autumn of 2012 (T1) and 2014 (T2). This project has taken a broad approach to developing schools' learning environments, and its implementation was not intended to have differential impacts on girls and boys. All students at each school were invited to participate in the survey. Parents provided consent for teachers to assess children's social skills and academic achievement. At total of 7,074 students in first through tenth grade were invited to participate in T1, although the parents of 1,430 students did not give permission to participate. Thus, T1 included 5,644 student evaluations, resulting in a response rate of $79.7 \%$. Teachers rated $96.6 \%$ of students whose parents gave permission to participate in the study.

At T2, the ninth and tenth graders who participated in the first survey had left compulsory schooling $(1,385$ students). In Norway, most students change schools between grades seven and eight, for which 1,082 students were not included in the T2 sample. A total of 2,915 (53.5\%) of the invited students participated in both T1 and T2. In 2012-13, 32\% of Norwegian schools had fewer than 100 students. In rural areas, many students receive their primary education in small classes that include multiple class levels. In this same school year, there were on average 13.5 students per teacher. Because of this contextual characteristic, only classes with 10 or more students were retained. Thus, the analysis ultimately included 2,266 students.

\subsection{Ethics}

Information explaining the purpose and procedure of the study was provided to parents and teachers, who were also assured that participants would be anonymous and that participation was voluntary. The survey was registered with the Norwegian Centre for Research Data (NSD for its initials in Norwegian) in accordance with Norwegian law.

\subsection{Instruments}

In Norway, each student is assigned a contact teacher. In the present study, the contact teacher of each student assessed his or her social skills and academic achievement. 
Social skills - Teachers' perceptions of students' social skills were measured using the Social Skills Rating System (SSRS) (Gresham \& Elliott, 1990), which is a standardised, norm-referenced scale. The SSRS is one of the most widely used instruments for measuring pro-social behaviours among children aged 3-18 years (Gamst-Klaussen, Rasmussen, Svartdal, \& Strømgren, 2014; Gresham, Elliott, Vance, \& Cook, 2011). The scale was previously translated into Norwegian (Ogden, 1995). The 30-item secondary-level teacher version of the social skills dimension was used in the present investigation. Teachers were asked to report the extent to which students complied with behaviors like 'attends to instruction', 'invites other to join' and 'compromises in conflicts'. In the original version of the SSRS, the items were assessed using a 3-point Likert scale, although the modified Norwegian version uses a 4-point Likert scale $(1=$ never, $2=$ sometimes, $3=$ often, $4=$ almost all the time) (Ogden, 2003).

In the present study, the measure of social skills resulted in a sum score calculated for both level 1 and level 2. Cronbach's alpha for the total sum score at the individual level was .95 at both T1 and T2. Several studies have supported the validity and reliability of the SSRS (Demaray et al., 1995; Gresham \& Elliott, 1990; Walthall, Konold, \& Pianta, 2005).

Academic achievement - Teachers' perceptions of students' academic achievement were also assessed using the SSRS (Gresham \& Elliott, 1990). The original SSRS measured academic achievement on a 9-item scale according to teacher ratings. In the present study, students' academic achievement in three subjects, Norwegian, mathematics and English, was measured on a 6-point Likert scale. SePU made this modification, as the Norwegian educational system assigns grades from 1 to 6 in secondary school, with 1 indicating very low competence and 6 very high competence. The same measurement system was used for all students from first to tenth grade in order to better compare their results. High correlations were previously found between this scale and test results for reading and mathematics skills (Topphol, Haug, \& Nordahl, 2017).

Students' individual academic achievements in each subject at $\mathrm{T} 2$ were considered to be dependent variables and at $\mathrm{T} 1$ to be independent variables. The sum score of the three subjects was used to measure students' academic achievement at the classroom level.

Control variables - The analysis was controlled for students' age, cultural background and class size. Age was determined by class level. Cultural background was grouped into 3 categories, Norwegian (96.3\%), Western minority $(0.8 \%)$ and non-Western minority $(3.7 \%)$, which were operationalised as dummy variables $(0=$ minority, $1=$ majority). Class sizes were grouped into 6 categories: $1=10-12$ students per class ( 57 classes), $2=$ $13-15$ students per class ( 45 classes), $3=16-18$ students per class ( 28 classes), $4=19-21$ students per class (10 classes), $5=22-24$ students per class ( 6 classes) and $6=$ more than 25 students per class ( 7 classes).

Gender - Both student gender and teacher gender were divided into 2 categories: 0=female, $1=$ male.

\subsection{Missing data}

The amount of missing data was generally low. For the continuous variables, $1.1 \%$ of cells in the data imported into the SPSS software had missing values. The little MCAR test showed that data were missing completely at random. Missing data were replaced at the item level using the expectation maximisation procedure. This interactive procedure used the current best guess of the value within the subscale instead of who was missing (Graham, 2009).

\subsection{Statistics}

The present study used a non-experimental longitudinal research design. Descriptive data were subjected to t-tests and correlation analyses. In general, the following guidelines for the strength of relationships, as determined by Pearson's $r$ (L. Cohen, Manion, \& Morrison, 2011), were used: 0-0.20 (very weak), $0.20-0.40$ (weak), $0.40-0.60$ (moderate), $0.60-0.80$ (strong) and 0.80-1.00 (very strong). Cohen's $d$ was used as a measure 
of the effect size of differences in the means. This measure is generally interpreted as small $(d=0.2)$, medium $(d=0.5)$ and large $(d=0.8)$ (J. Cohen, 1988). However, Hattie (2009) problematized Cohen's effect sizes for judging educational outcomes, as small effect sizes might have large effects on some students' learning. Keith's (2006) modified these rules for school learning as follows: $0.05=$ too small of an effect to be considered meaningful, above $0.05=$ small but meaningful effect, $0.10=$ moderate effect and $0.25=$ large effect .

Given the research questions, three-level univariate regression analyses were implemented through building a random intercept model. Multilevel analysis is a useful methodology for analysing the effects or influence of a social context on individual behaviours or achievements for hierarchically structured data. The variance in an outcome variable can operate at different levels, such as the student level (level 1), the class level (level 2) and the school level (level 3). In this case, an outcome variable is a combination of between-group differences (between classes or schools) and within-group differences (between students) (Snijders \& Bosker, 2012).

All variables were group-mean centred. At level 1, the individual student level: Subtracting each variable at the student level from the class mean (student value - class mean). At level two, mean class scores: Subtracting each variable at the class level from the total mean (class mean - total mean).

Three models for each subject and each gender were built using maximum-likelihood (ML) estimation. In step 1, a random-intercept-only model with no predictors was used to partition the variance in outcomes into individual, class and school levels. In step 2, the level-one control predictors of age and cultural background were added to previous social skills and academic achievement. Furthermore, social skills and academic achievement at level 2 (T1) were added to investigate whether previous social skills or academic achievement at the class level had statistically significant influences on boys' and girls' individual academic achievement at T2. The gender of teacher and gender ratio variable (T1) was also added. The gender ratio variable was computed by dividing the number of boys by the total number of students in each class. Preliminary analyses were conducted to ensure that assumptions of normality, linearity, homoscedasticity, skewness and kurtosis were not violated. All analyses were carried out in the SPSS software, version 23. The control of variables in the multilevel analysis was performed in the STATA software.

\section{Results}

\subsection{Descriptive statistics}

Table 2 presents the mean scores and standard deviations of academic performance in Norwegian, mathematics and English and of social skills for boys and girls according to the SSRS.

\section{Table 2}

Descriptive statistics of academic performance of participants $(N=2,266)$

\begin{tabular}{lccrc}
\hline \multicolumn{1}{c}{ Variables } & $\begin{array}{c}\text { Mean score (SD) } \\
\text { Boys }(n=1,128)\end{array}$ & $\begin{array}{c}\text { Mean score (SD) } \\
\text { Girls }(n=1,138)\end{array}$ & Cohen's $d$ & p-value \\
\hline Norwegian T1 & $3.85(1.22)$ & $4.33(1.09)$ & -0.41 & .000 \\
Norwegian T2 & $3.81(1.20)$ & $4.37(1.06)$ & -0.48 & .000 \\
Mathematics T1 & $4.13(1.22)$ & $4.20(1.11)$ & -0.06 & .148 \\
Mathematics T2 & $4.11(1.30)$ & $4.21(1.19)$ & -0.08 & .058 \\
English T1 & $3.67(1.24)$ & $4.04(1.10)$ & -0.31 & .000 \\
English T2 & $3.81(1.32)$ & $4.14(1.15)$ & -0.27 & .000 \\
Social skills T1 & $2.85(0.52)$ & $3.11(0.45)$ & -0.51 & .001 \\
Social skills T2 & $2.96(0.51)$ & $3.23(0.45)$ & -0.54 & .001 \\
\hline
\end{tabular}

In this sample, boys were more likely than girls to be assessed as low achievers in Norwegian and English and as having weaker social skills at both measurement points. No statistically significant gender differences were found in mathematics per teacher assessments. The descriptive analysis found large differences at a 
Gender differences in academic achievement: A matter of contextual classroom influence?

significance level of .001 among classes in both social skills $\mathrm{T} 1(\min$ score $=2.41$, $\max$ score $=3.89)$ and academic achievement $\mathrm{T} 1$ ( $\min$ score $=2.92$, max score $=5.05$ ). The gender ratio also differed between classes. The proportion of boys in classes varied from $20-80 \%$ of the students. Table 3, presents how female and male teachers rated boys' and girls' academic achievement and social skills at both measure points.

Table 3

Descriptive statistics of academic performance of participants rated by teachers $(N=2,266)$

\begin{tabular}{|c|c|c|c|c|c|c|}
\hline \multicolumn{3}{|c|}{ Boys } & & \multicolumn{3}{|c|}{ Girls } \\
\hline Variables & $\begin{array}{l}\text { Mean score } \\
(\mathrm{SD}) \\
\text { Male teacher } \\
\text { ratings } \\
(\mathrm{n}=187)\end{array}$ & $\begin{array}{c}\text { Mean score } \\
(\mathrm{SD}) \\
\text { Female } \\
\text { teacher } \\
\text { ratings } \\
(\mathrm{n}=927)\end{array}$ & Cohen's $d$ & $\begin{array}{c}\text { Mean score } \\
(\mathrm{SD}) \\
\text { Male teacher } \\
\text { ratings } \\
(\mathrm{n}=194)\end{array}$ & $\begin{array}{c}\text { Mean score } \\
\text { (SD) } \\
\text { Female } \\
\text { teacher } \\
\text { ratings } \\
(\mathrm{n}=931)\end{array}$ & Cohen's $d$ \\
\hline Norwegian T1 & $3.55(1.17)$ & $3.91(1.22)$ & $-0.29 * * *$ & $4.21(1.01)$ & $4.35(1.10)$ & -0.13 \\
\hline Norwegian T2 & $3.58(1.14)$ & $3.86(1.21)$ & $-0.23 * *$ & $4.40(0.88)$ & $4.36(1.10)$ & 0.04 \\
\hline Mathematics T1 & $3.79(1.26)$ & $4.19(1.21)$ & $-0.33 * * *$ & $4.02(1.05)$ & $4.23(1.11)$ & $-0.19 * *$ \\
\hline Mathematics T2 & $3.74(1.32)$ & $4.19(1.29)$ & $-0.35 * * *$ & $4.07(1.15)$ & $4.24(1.20)$ & -0.14 \\
\hline English T1 & $3.51(1.27)$ & $3.70(1.23)$ & -0.15 & $4.01(1.06)$ & 4.03 (1.12) & -0.02 \\
\hline English T2 & $3.66(1.30)$ & $3.84(1.32)$ & -0.13 & $4.33(1.02)$ & $4.10(1.17)$ & $0.20 * *$ \\
\hline Social skills T1 & $2.82(0.47)$ & $2.86(0.53)$ & -0.08 & $3.08(0.38)$ & $3.11(0.47)$ & -0.07 \\
\hline Social skills T2 & $2.95(0.47)$ & $2.96(0.52)$ & -0.02 & $3.22(0.43)$ & $3.23(0.46)$ & -0.03 \\
\hline
\end{tabular}

In the present study 187 boys and 194 girls were rated by male teachers and 927 boys and 931 girls were rated by female teachers. The results showed that male teachers rated boys statistically significant more negative than female teachers in Norwegian and mathematics. The same pattern seemed to apply to their assessment of the girls as well, but only in mathematics. In language subjects, there were no statistically significant gender differences in teacher ratings of girls, except from in English (T2), were male teachers assessed girls over boys. In social skills, there were no differences between male and female teacher ratings.

Table 4 presents the correlations between academic achievement at the individual level at $\mathrm{T} 2$ and academic achievement and social skills at the individual level (level 1) and the class level (level 2) at T1.

\section{Table 4}

Correlations between academic achievement (T2) and prior academic achievement and social skills

\begin{tabular}{|c|c|c|c|c|c|c|c|c|c|}
\hline \multirow{2}{*}{$\begin{array}{c}\text { Academic } \\
\text { achievement T2 }\end{array}$} & \multirow[b]{2}{*}{$n$} & \multicolumn{8}{|c|}{ Class level } \\
\hline & & 3 & 4 & 5 & 6 & 7 & 8 & 9 & 10 \\
\hline $\begin{array}{l}\text { Social skills T1 } \\
\text { (individual level) }\end{array}$ & 2266 & $.33 * * *$ & $.47 * * *$ & $.32 * * *$ & $.37 * * *$ & $.56 * * *$ & $.65 * * *$ & $.31 * * *$ & $.46 * * *$ \\
\hline $\begin{array}{l}\text { Social skills T1 } \\
\text { (class level) }\end{array}$ & 153 & .02 & .08 & .01 & .04 & .14 & $.41 * *$ & .10 & .06 \\
\hline $\begin{array}{l}\text { Academic } \\
\text { achievement T1 } \\
\text { (individual level) }\end{array}$ & 2266 & $.56 * * *$ & $.73 * * *$ & $.76^{* * *}$ & $.77 * * *$ & $.81 * * *$ & $.87 * * *$ & $.72 * * *$ & $.65^{* * *}$ \\
\hline $\begin{array}{l}\text { Academic } \\
\text { achievement T1 } \\
\text { (class level) }\end{array}$ & 153 & .10 & $.11^{*}$ & .02 & .09 & $.27 * * *$ & $.44 * * *$ & .13 & .06 \\
\hline
\end{tabular}

Relationships between teacher-assessed academic achievement at T2 and level-one social skills and academic achievement at T1 were consistently strongly positive and significant. Relationships between the dependent variable at level 1 and the exploratory variables at level 2 were much weaker and only significant at class level 8 for social skills and at class levels 7 and 8 for academic achievement. Class level 8 had few students, which could be one reason for this finding. These results indicated that the correlations between variables at level 1 were stronger than the correlations between level 1 and level 2. 
Gustavsen, A. M.

\subsection{Multilevel analyses}

Multilevel analyses were performed to investigate the research questions. Six models were built: one for girls and one for boys in each of three dependent variables of academic achievement in Norwegian, mathematics and English at the second measurement point. Table 5 and 6 presents the results of the multilevel analyses for girls and boys separately in each subject.

Table 5

Random intercept model, academic achievement for girls $(N=1138)$

\begin{tabular}{|c|c|c|c|c|c|c|c|c|c|c|c|c|}
\hline \multirow[b]{3}{*}{ Fixed effects } & \multirow{3}{*}{$\begin{array}{c}\text { Norwegian } \\
\text { M0 } \\
\text { Estimate }\end{array}$} & \multirow[b]{3}{*}{ SE } & \multirow[b]{2}{*}{ M1 } & \multicolumn{3}{|c|}{ Mathematics } & \multicolumn{4}{|c|}{ English } & \multirow{2}{*}{\multicolumn{2}{|c|}{ M1 }} \\
\hline & & & & & M0 & & M1 & & M0 & & & \\
\hline & & & Estimate & SE & Estimate & SE & Estimate & SE & Estimate & SE & Estimate & SE \\
\hline Intercept & $4.377 * * *$ & 0.037 & $4.451 * * *$ & 0.213 & $4.231 * * *$ & 0.050 & $4.777 * * *$ & 0.237 & $4.143 * * *$ & 0.038 & $4.240 * * *$ & 0.233 \\
\hline Level 1 & & & & & & & & & & & & \\
\hline Age & & & $-0.049 * *$ & 0.016 & & & $-0.072 * * *$ & 0.018 & & & 0.001 & 0.018 \\
\hline Cultural background & & & -0.004 & 0.124 & & & -0.144 & 0.144 & & & $-0.271 *$ & 0.137 \\
\hline Class size & & & 0.016 & 0.024 & & & -0.003 & 0.025 & & & 0.028 & 0.024 \\
\hline Norwegian T1 & & & $0.390 * * *$ & 0.039 & & & $0.146^{* *}$ & 0.046 & & & $0.224 * * *$ & 0.044 \\
\hline Mathematics T1 & & & $0.116 * *$ & 0.035 & & & $0.427 * * *$ & 0.041 & & & $0.147 * * *$ & 0.039 \\
\hline English T1 & & & $0.166 * * *$ & 0.039 & & & $0.150^{* *}$ & 0.045 & & & $0.398 * * *$ & 0.043 \\
\hline Social skills $\mathrm{T} 1$ & & & $0.287 * * *$ & 0.076 & & & $0.302 * *$ & 0.088 & & & 0.097 & 0.084 \\
\hline Level 2 & & & & & & & & & & & & \\
\hline Social skills T1 & & & -0.196 & 0.120 & & & -0.102 & 0.133 & & & -0.160 & 0.134 \\
\hline Achievement $\mathrm{T} 1$ & & & $0.431 * * *$ & 0.095 & & & $0.420 * * *$ & 0.104 & & & $0.367 * *$ & 0.104 \\
\hline Gender ratio $\mathrm{T} 1$ & & & -0.206 & 0.294 & & & -0.499 & 0.322 & & & -0.173 & 0.324 \\
\hline Male teacher & & & $0.166^{*}$ & 0.078 & & & 0.013 & 0.088 & & & $0.185^{*}$ & 0.087 \\
\hline$-2 \mathrm{LL}$ & 3343.341 & & 2544.324 & & 3610.122 & & 2867.831 & & 3536.059 & & 2769.357 & \\
\hline AIC & 3351.341 & & 2574.324 & & 3618.122 & & 2897.831 & & 3544.059 & & 2799.357 & \\
\hline BIC & 3371.489 & & 2649.233 & & 3638.270 & & 2972.740 & & 3564.207 & & 2874.266 & \\
\hline Residual variance & & & & & & & & & & & & \\
\hline Levell & 1.057551 & & 0.557750 & & 1.342339 & & 0.764531 & & 0.682127 & & 0.687152 & \\
\hline Level2 & 0.055610 & & 0.051445 & & 0.048978 & & 0.053747 & & 0.080424 & & 0.074899 & \\
\hline School expl.\% & 0 & & 2.48 & & 1.33 & & 1.08 & & 0 & & 0 & \\
\hline Class expl.\% & $5.00^{*}$ & & $8.24 * * *$ & & $3.47 * *$ & & $6.50 * *$ & & $3.02 *$ & & $9.83^{*}$ & \\
\hline Individual expl.\% & $95.00 * * *$ & & $89.28 * * *$ & & $95.20 * * *$ & & 92.42 *** & & $96.98 * * *$ & & $90.17 * * *$ & \\
\hline
\end{tabular}

\section{Table 6}

Random intercept model, academic achievement for boys $(N=1128)$

\begin{tabular}{|c|c|c|c|c|c|c|c|c|c|c|c|c|}
\hline \multirow[b]{3}{*}{ Fixed effects } & \multirow{3}{*}{$\begin{array}{c}\text { Norwegian } \\
\text { M0 } \\
\text { Estimate }\end{array}$} & \multirow[b]{3}{*}{ SE } & \multirow{3}{*}{$\begin{array}{c}\text { M1 } \\
\text { Estimate }\end{array}$} & \multicolumn{3}{|c|}{ Mathematics } & \multicolumn{4}{|c|}{ English } & \multirow[b]{2}{*}{ M1 } & \multirow[b]{3}{*}{ SE } \\
\hline & & & & & M0 & & M1 & & M0 & & & \\
\hline & & & & SE & Estimate & SE & Estimate & SE & Estimate & SE & Estimate & \\
\hline Intercept & $3.821 * * *$ & 0.049 & $3.779 * * *$ & 0.239 & $4.143 * * *$ & 0.069 & $4.577 * * *$ & 0.253 & $3.810 * * *$ & 0.038 & $4.098 * * *$ & 0.264 \\
\hline Level 1 & & & & & & & & & & & & \\
\hline Age & & & -0.018 & 0.018 & & & $-0.095^{* * * *}$ & 0.019 & & & 0.015 & 0.020 \\
\hline Cultural background & & & $0.260 *$ & 0.126 & & & 0.145 & 0.132 & & & -0.199 & 0.135 \\
\hline Class size & & & -0.038 & 0.025 & & & -0.045 & 0.028 & & & -0.012 & 0.028 \\
\hline Norwegian T1 & & & $0.420 * * *$ & 0.043 & & & $0.129 * *$ & 0.045 & & & $0.260 * * *$ & 0.046 \\
\hline Mathematics T1 & & & $0.129 * * *$ & 0.036 & & & $0.515^{* * *}$ & 0.037 & & & $0.109 * *$ & 0.038 \\
\hline Social skills $\mathrm{T} 1$ & & & $0.176^{* *}$ & 0.071 & & & $0.173^{*}$ & 0.074 & & & -0.094 & 0.076 \\
\hline Level 2 & & & & & & & & & & & & \\
\hline Social skills T1 & & & 0.195 & 0.136 & & & 0.018 & 0.143 & & & 0.059 & 0.152 \\
\hline Achievement $\mathrm{T} 1$ & & & 0.196 & 0.106 & & & $0.259^{*}$ & 0.111 & & & $0.308 *$ & 0.118 \\
\hline Gender ratio $\mathrm{T} 1$ & & & 0.274 & 0.329 & & & 0.043 & 0.349 & & & 0.089 & 0.243 \\
\hline Male teacher & & & -0.115 & 0.088 & & & -0.109 & 0.092 & & & -0.103 & 0.096 \\
\hline$-2 \mathrm{LL}$ & 3602.023 & & 2753.294 & & 3749.148 & & 2846.272 & & 3809.429 & & 2910.906 & \\
\hline AIC & 3610.023 & & 2783.294 & & 3757.148 & & 2876.272 & & 3817.429 & & 2940.906 & \\
\hline $\mathrm{BIC}$ & 3630.136 & & 2858.190 & & 3777.261 & & 2951.167 & & 3837.524 & & 3015.801 & \\
\hline Level2 & 0.059183 & & 0.084278 & & 0.112276 & & 0.088064 & & 0.087989 & & 0.111515 & \\
\hline School expl.\% & 1.04 & & 0 & & 3.34 & & 1.47 & & 0.30 & & 0.33 & \\
\hline Class expl.\% & $4.11^{*}$ & & $11.13 * * *$ & & $6.68^{*}$ & & $10.77^{* *} *$ & & $5.09 *$ & & $12.67 * *$ & \\
\hline Individual expl.\% & $94.85 * * *$ & & $88.87 * * *$ & & $89.97 * * *$ & & $89.23^{* * * *}$ & & $94.62 * * *$ & & $87.33 * * *$ & \\
\hline
\end{tabular}

For girls, the null model for each subject showed that $8.24 \%, 6.60 \%$ and $9.83 \%$ of the variance in Norwegian, mathematics and English achievement was among the classes $(p<.001)$ in the sample and that $89.28 \%, 92.42 \%$ and $90.17 \%$ of variance was among the students $(p<.001)$. No statistically significant differences were found in any subject among schools for girls. 
The multilevel analysis showed that teacher-rated social skills at the class level did not significantly contribute to academic achievement in any of the subjects for girls, although social skills at the individual level did significantly contribute to achievement in Norwegian (.287 points) and mathematics (.302 points). The class mean of academic achievement seemed to be more important for girls' achievement in Norwegian than the class mean of social skills and significantly contributed towards achievement in all subjects. Male teachers rated girls statistically significant higher than female teachers, in Norwegian and English. The number of boys in a class did not seem to matter.

For boys, the null model for each subject showed that $11.13 \%, 10.77 \%$ and $12.67 \%$ of the variance in Norwegian, mathematics and English achievement was among the classes $(p<001)$ in the sample and that $88.87 \%, 89.23 \%$ and $87.33 \%$ of variance was among the students $(p<.001)$. Similar to girls, no statistically significant differences were found in any subject among schools.

The multilevel analysis showed that teachers' assessment of social skills at the class level did not significantly contribute to academic achievement in any of the subjects for boys, but social skills at the individual level significantly contributed to achievement in Norwegian ( 0.176 points) and mathematics $(0.176$ points). The contribution of social skills in boys towards achievement in Norwegian and mathematics was lower ( 0.176 and 0.176 points, respectively) than in girls ( 0.287 and 0.302 points, respectively). These differences were not statistically significant because the confidence intervals for boys and girls overlapped in each subject.

The class mean of academic achievement seemed to be more important than social skills for boys' individual academic achievement, as the prior significantly contributed towards achievement in mathematics and English. In Norwegian, the contextual effect was not statistically significant for boys, although it was significant for girls. Upon comparing the results for boys and girls, the estimated effects of contextual variables were larger for girls, even though these differences were not statistically significant because the confidence intervals for boys and girls overlapped in each subject. Even so, the impact of a one-unit increase in academic achievement at the class level increased academic achievement at the individual level in mathematics by 0.420 points for girls and 0.259 points for boys. Finally, either the gender of teacher or the gender ratio did influence academic achievement for boys.

\section{Discussion}

The current study utilised multilevel analyses to better understand the extent to which teacher assessments of boys' and girls' social skills and academic achievement at the class level, as well as the teachers' gender and the gender ratio of the classroom, might explain variance in teacher assessments of individual academic achievement in Norwegian, mathematics and English.

The main finding of the present study was that previous teacher-rated academic achievement at the class level significantly contributed to boys' and girls' individual academic achievement two years later in mathematics and English. In Norwegian, the contextual effect of academic achievement was only statistically significant for girls. For girls, the gender of teacher had a statistically significant influence for the assessment in Norwegian and English, not in mathematics. For boys, the teachers' gender had no influence at all. Social skills at the class level and the gender ratio at T1 did not significantly contribute to either boys' or girls' academic achievement at $\mathrm{T} 2$.

The present study suggested that higher mean levels of academic achievement in the classroom seemed to have a positive effect on boys' and girls' individual academic achievement in mathematics and English. This means that a student, given his or her initial characteristics, can be expected to perform better in a class with a higher than average achievement level than a similar student in a class with a lower than average achievement level (De Fraine et al., 2003). These findings are in line with previous studies reporting that academic achievement at the class level predicts achievement scores at the individual level (De Fraine et al., 2003; Hendriks et al., 2011). In the present study, the results showed a student gender difference only for Norwegian, 
wherein girls' academic achievement at the class level significantly impacted their individual academic achievement two years later. Although the confidence intervals for boys and girls overlap, the results indicated that the contextual influence of average academic achievement in the classroom is more important for the teacher-assessed academic achievement of girls than for that of boys. Furthermore, the teacher-assessed achievement scores were found to be higher for girls at the class level than for boys in Norwegian and Mathematics but not in English, indicating that higher mean levels of achievement have a greater effect on the teacher-assessed individual academic achievement of girls than that of boys. A similar finding was observed in another study, wherein the ability of a group as a whole in mathematics was found to have a more positive effect on highly able girls than on highly able boys (Catsambis, 1999). However, other findings have differed from the present study who did not found a contextual effect of academic achievement for boys. For instance, boys who began classes with a relatively high average achievement level in the Dutch language showed better development in this subject compared to boys who started classes with a relatively low average (Hendriks et al., 2011). In this latter study, a sample of 2,498 students between 11 and 15 years distributed among 155 classes during their first year of Dutch secondary school was considered. In the Netherlands, the class size is larger than in Norway, so the study set the minimum number of same-sex students per class to be 9 for boys and to be 10 for girls. The sample in this study also had a larger mean age and a more equal number of boys and girls in each class than in the present study, which might explain the differences in the results.

Although most studies did not find that the teacher's gender influences academic achievements (Antecol et al., 2015; Burusic et al., 2012; Cho, 2012; de Zeeuw et al., 2014; Ehrenberg et al., 1995; Helbig, 2012; Holmlund \& Sund, 2008; Neugebauer et al., 2011; Sokal \& Katz, 2008), there are some studies who report an influence of same-gender teacher on academic achievements (Ammermüller \& Dolton, 2006; Dee, 2007). The results of the current study are not in line with previous research. In the present study, gender of teacher had statistically influence for the assessment of girls' academic achievement in language subjects, not in mathematics. Teachers' gender had no influence on the assessment in any subject for boys. These results indicate that girls are more likely to get higher assessments from male teachers, but that the teacher's gender cannot explain the variation in academic achievement for boys. Furthermore, it seemed like female teachers rated boys more favorable than male teachers in Norwegian and mathematics. There were less gender differences in assessment of girls' academic achievement. The results must be interpreted with caution because of a low proportion of male teacher assessments. The data only shows how many student assessments were made by male and female teachers, the number of male and female teachers was not visible. Anyway, a Norwegian study of more than 18000 students also reported that male teachers assessed boys' academic achievement lower than female teachers, but the study did not include multi-level analysis (Nordahl, Egelund, Nordahl, \& Sunnevåg, 2017).

With respect to social skills, the present study showed that high or low average social skills of a class did not predict boys' or girls' academic achievement in any subject. One reason for the greater power of variables at the individual level compared to the class level may be that both independent and dependent variables are often based on individual ratings (Urdan, 2004). Furthermore, the current study only examined the direct effect of social skills (at a class level) on students' individual academic achievements. The average social skills of a class might have an indirect effect, as it can be assumed that students may learn successful social skills at school and competently perform specific skills through observing and imitating classmates with high social skills (Veronneau \& Dishion, 2011; Wentzel, 2005). Thus, classes with high average social skills might encourage students' individual development of social skills. High-achieving classes have also been found to influence individual student characteristics other than academic achievement in potentially positive and negative ways. For example, higher mean levels of achievement in a class seemed to decrease students' enjoyment and increase their anxiety and anger in mathematics (Frenzel, Pekrun, \& Goetz, 2007).

As mentioned, social skills at the class level did not predict boys' or girls' academic achievement in any subject, although social skills at the individual level appeared to be more important. The longitudinal effects of social skills on academic achievement at the individual level have also been reported in other studies (Caprara et al., 2000; Jennings \& DiPrete, 2010; Konold et al., 2010). The descriptive results of the present study showed 
that teachers tend to assess girls as having greater social skills than boys. There were no gender of teaacher differences. Furthermore, the estimated influence of girls' social skills on academic achievement in Norwegian and Mathematics was larger than for boys. These findings are in agreement with previous research that has suggested that students with stronger social skills have better academic abilities, even after controlling for their actual academic skills (Baker et al., 2015). Teachers might consider girls with good social skills as high academic achievers in Norwegian and mathematics, although this relationship is not as strong for boys. This finding indicates that girls obtain greater advantages in comparison to boys in displaying social skills that fulfil school norms (Diprete \& Jennings, 2012) and that girls can possibly obtain higher grades by adapting to teachers' expectations and perceptions.

The differential influence of social skills at the individual level and of previous academic achievement at the class level on boys' and girls' academic achievement in Norwegian and mathematics might have several explanations in the classroom context. One explanation can be related to differences in boys' and girls' peer subcultures, as the peer groups of girls display more conducive study attitudes and behaviours than those of boys (Vantieghem \& Van Houtte, 2015). This gender difference was found to be largely responsible for boys' lower achievement (Houtte, 2004). Another explanation can be attached to gender stereotype. Previous studies have documented gender-stereotyped assessments by teachers in regard to students' academic skills (Catsambis et al., 2012; Tiedemann, 2002) resulting from stereotyped expectations for students' behaviour and social skills according to gender (American Association of University Women, 1992).

The big-fish-little-pond effect (BFLPE) might also explain differential influences on boys and girls. This model hypothesises that it is better to be a big fish in a little pond (i.e. a good student in a reference group of average ability) than to be a small fish in a big pond (i.e. a good student in a reference group of high ability) (Marsh \& Hau, 2003). According to the present study, boys seemingly preferred to fit the model of a big fish in a little pond in Norwegian, as the context effect was not statistically significant. Also, in mathematics, their achievement estimates were lower than those of girls. Meanwhile, for girls, the estimates at the class level were stronger both in Norwegian and mathematics, indicating their seeming preference to fit the model of a small fish in a big pond.

In the current study, the null model for boys' and girls' academic achievement in Norwegian, mathematics and English showed that most of the variance in the sample was between students (between 87-92\%) and little of the variance was between classes (between 6-13\%). Indicating, there is a large proportion of unexplained variance at the individual level. No significant differences were found in any subject among schools. Several school variables have been documented as important for students' academic achievement (Opdenakker, Van Damme, De Fraine, Van Landeghem, \& Onghena, 2002; Rutter, 1979; Sellström \& Bremberg, 2006), but the influence of academic achievement at the school level decreases when achievement at the class level is taken in account (Scheerens \& Creemers, 1989).

The proportion of boys and girls in a classroom in the present study did not seem to affect their academic achievement in any subject. Likewise, a previous Norwegian study did not find any effect of gender ratio in mathematics classes (Manger \& Gjestad, 1997). A different finding was encountered in another study in Dutch language classes where language achievement was higher for students who attended classes with a large proportion of girls (De Fraine et al., 2003). Distinct results may be due to contextual differences. For example, the percentage of girls in a classroom in a Belgian study was documented to range from 0-100\%, wherein 26 all-boy classes and 33 all-girl classes were present in a sample of 149 classes. In Norway, classes with only boys or only girls do not exist.

\subsection{Strengths and limitations}

One strength of the current study was its inclusion of teacher-assessed social skills and academic achievement in three different subjects for 2,266 students in the first to eighth grade at an initial measurement 
point and in the third to tenth grade at a subsequent measurement point. The sample size was large, and the use of the same measurement tools at both time points made comparisons across grade levels possible. The survey also had a high response rate, and the sample included schools from different locations in Norway.

A potential methodological weakness of the current study was that the class sizes in the sample were small, and students from class level three to class level seven were overrepresented in the sample, which might influence the results. The number of male and female teachers are not documented, only number of teacher ratings made by female and male teachers. Unfortunately, the study did not record student socioeconomic background. Also, academic achievement and social skills were only assessed by teachers. This study therefore is lacking in perceptions from other informants. However, compared to parents' ratings, teacher ratings have been shown to be more reliable (Tourangeau, Nord, Lê, Sorongon, \& Najarian, 2009) and to generally explain more variance in academic achievement (Konold et al., 2010).

The results showed that the variance in academic achievements were largest between students. In the present study, of individual differences of the students, it was only controlled for age, cultural background and previous social skills and academic achievement. The study would have been strengthened by including more individual variables, like personality, but there were no more individual teacher rated variables of students in the data.

It was not clear whether teachers' assessments reflected students' actual academic achievement and social skills or simply their academic achievement and social skills as perceived by teachers. Teachers for each subject subjectively assessed students' academic achievement, with 1 indicating very low competence and 6 very high competence, rather than objectively evaluating achievement through test scores. In this respect, teachers indicated their perception of what students would do or how students would perform in specific situations rather than actual observation of students in such scenarios. For this reason, the SSRS must be considered an indirect measure of social skills and academic achievement (Gresham \& Lambros, 1998). Consequently, social skills might be a proxy for unmeasured processes, such as stereotyped perceptions that operate on the basis of gender (Konold et al., 2010).

\subsection{Practical implications and suggestions for future research}

The findings of the present study highlight some important educational implications for teachers and others interested in student learning. First, teacher assessment of students' social skills at an individual level seems to impact their assessments of students' academic achievement. For the past 20 years, teachers have rated cooperative social skills, such as paying attention and following directions and classroom rules, as the most important behaviour for classroom success (Gresham \& Elliott, 1990, 2008). The descriptive results in the present study showed that teachers assess the social skills of girls to be much higher than those of boys. Many teachers seem to define the ideal student as female (Younger, Warrington, \& Williams, 1999). Teachers might ask themselves to what extent gender differences in social skills are a result of actual gender differences or of gender stereotypes and expectations. Previous studies have found that teachers may distinctly evaluate girls and boys with the same behaviours and social skills (American Association of University Women, 1992). In the present study, the results showed that girls are more likely to get better assessment in Norwegian and English of male teachers than of female teachers. This knowledge might have practical implications. An equitable educational system requires teachers to become aware of and resistant to stereotypes (Retelsdorf et al., 2014).

Second, in Norway, curriculum is only in place for academic learning and not for social learning. Modern society and professions place an equal demand on social interaction skills as well as skills in reading, writing and billing (Ogden, 2015). A US study of children from kindergarten through fifth grade argued that gender differences in the acquisition of teacher assessed social and behavioural skills offer a significant explanation of the gender gap in academic achievement (Diprete \& Jennings, 2012). One reason might be that subjective teacher grading has a stronger relationship with student social skills than objective test scores (Diprete \& Jennings, 2012). Despite gender differences, boys and girls are more similar than different, so different teaching 
techniques, single-sex classes or schools, and so on are not required (Hattie, 2009). However, curriculum for social learning may be necessary in order to educate teachers on social skill development in children of different ages and thereby inform their expectations as well as enable teachers to commit more time to social skills training at school. The development of social skills has also been shown to be important for the development of academic skills and vice versa. For example, a bi-directional relationship was found between social skills and academic achievement (Chen, Huang, Chang, Wang, \& Li, 2010). Also, intervention research has shown that school-based programmes that increase students' social skills often also improve academic achievement (Durlak, Weissberg, Dymnicki, Taylor, \& Schellinger, 2011). Practitioners can use such knowledge on the development of social skills and academic achievement to enhance both competencies.

The perceptions of students belonging to the same classroom of their learning environment were found to differ considerably as a result of individual characteristics or their exposure to different learning environments (Bru, Stephens, \& Torsheim, 2002), likely. Teachers may differentially reprimand or encourage students in the same class, and/or students belonging to different peer sub-groups may have different approaches to learning (Stornes, Bru, \& Idsoe, 2008). For this reason, in future research, it could be interesting to more closely examine different subgroups of boys and girls.

\section{References}

American Association of University Women. (1992). How schools shortchange girls. The AAUW Report. New York: Marlowe \& Company.

Ammermüller, A., \& Dolton, P. (2006). Pupil-teacher gender interaction effects on scholastic outcomes in England and the USA (Vol. 06-60): ZEW - Zentrum für Europäische Wirtschaftsforschung / Center for European Economic Research.

Antecol, H., Ozbeklik, S., \& Eren, O. (2015). The effect of teacher gender on student achievement in primary school. Journal of Labor Economics, 33(1), 63-89.

Arens, A. K., Morin, A. J. S., \& Watermann, R. (2015). Relations between classroom disciplinary problems and student motivation: Achievement as a potential mediator? Learning and Instruction, 39, 184-193.

Backe-Hansen, E., Walhovd, K. B., \& Huang, L. (2014). Kjønnsforskjeller i skoleprestasjoner. En kunnskapsoppsummering [Gender differences in academic achievement. A summary of knowledge]. Retrieved from http://www.hioa.no/Om-HiOA/Senter-for-velferds-og-arbeidslivsforskning/NOVA/Publikasjonar/Rappo rter/2014/Kjoennsforskjeller-i-skoleprestasjoner

Baker, C. N., Tichovolsky, M. H., Kupersmidt, J. B., Voegler-Lee, M. E., \& Arnold, D. H. (2015). Teacher (mis)perceptions of preschoolers' academic skills: predictors and associations with longitudinal outcomes. Journal of Educational Psychology, 107(3), 805-820.

Bronfenbrenner, U. (1989). Ecological systems theory. In R. Vasta (Ed.), Six theories of child development: Revised formulations and current issues (Vol. 6). New York: Teachers College Press.

Bronfenbrenner, U., \& Morris, P. A. (2006). The bioecological model of human development. In R. M. Lerner \& W. Damon (Eds.), Handbook of child psychology: Theoretical models of human development (6th ed., Vol. 1, pp. 793 - 828). Hoboken, N.J.: John Wiley \& Sons.

Bru, E., Stephens, P., \& Torsheim, T. (2002). Students' perceptions of class management and reports of their own misbehavior. Journal of School Psychology, 40(4), 287-307.

Burusic, J., Babarovic, T., \& Seric, M. (2012). Differences in elementary school achievement between girls and boys: Does the teacher gender play a role? European Journal of Psychology of Education, 27(4), 523-538. https://doi.org/10.1007/s10212-011-0093-2

Caemmerer, J. M., \& Keith, T. Z. (2015). Longitudinal, reciprocal effects of social skills and achievement from kindergarten to eighth grade. Journal of School Psychology, 53(4), 265-281.

https://doi.org/10.1016/j.jsp.2015.05.001

Caprara, G. V., Barbaranelli, C., Pastorelli, C., Bandura, A., \& Zimbardo, P. G. (2000). Prosocial foundations of 
children's academic achievement. Psychological Science, 11(4), 302-306.

Catsambis, S. (1999). To track or not to track? The social effects of gender and middle school tracking. Research in Sociology of Educationa and Socialization, 12, 135-163.

Catsambis, S., Mulkey, L. M., Buttaro, A., Steelman, L. C., \& Koch, P. R. (2012). Examining gender differences in ability group placement at the onset of schooling: The role of skills, behaviors, and teacher evaluations. Journal of Educational Research, 105(1), 8-20.

Chen, X., Huang, X., Chang, L., Wang, L., \& Li, D. (2010). Aggression, social competence, and academic achievement in Chinese children: a 5-year longitudinal study. Development and psychopathology, 22(3), 583. https://doi.org/10.1017/S0954579410000295

Cho, I. (2012). The effect of teacher-student gender matching: Evidence from OECD countries. Economics of Education Review, 31(3), 54-67. https://doi.org/10.1016/j.econedurev.2012.02.002

Cohen, J. (1988). Statistical power analysis for the behavioral sciences. Hillsdale, N. J.: Laurence Erlbaum.

Cohen, L., Manion, L., \& Morrison, K. (2011). Research methods in education. London: Routledge.

Cornwell, C. M., Mustard, D. B., \& Parys, J. V. (2013). Noncognitive skills and the gender disparities in test scores and teacher assessments: Evidence from primary school. Journal of Human Resources, 48(1), 236-264.

De Boer, H., Bosker, R. J., Van Der Werf, M. P. C., \& Graesser, A. C. (2010). Sustainability of teacher expectation bias effects on long-term student performance. Journal of Educational Psychology, 102(1), 168-179. https://doi.org/10.1037/a0017289

De Fraine, B., Van Damme, J., Van Landeghem, G., Opdenakker, M.-C., \& Onghena, P. (2003). The effect of schools and classes on language achievement. British Educational Research Journal, 29(6), 841-859. https://doi.org/10.1080/0141192032000137330

De Jong, R., \& Westerhof, K. (2001). The quality of student ratings of teacher behaviour. Learning Environments Research, 4(1), 51-85. https://doi.org/10.1023/A:1011402608575

de Zeeuw, E. L., van Beijsterveldt, C. E. M., Glasner, T. J., Bartels, M., de Geus, E. J. C., \& Boomsma, D. I. (2014). Do children perform and behave better at school when taught by same-gender teachers? Learning and Individual Differences, 36, 152-156. https://doi.org/10.1016/j.lindif.2014.10.017

Dee, T. S. (2007). Teachers and the gender gaps in student achievement. Journal of Human Resources, 42(3), 528-554.

Demaray, M. K., Ruffalo, S. L., Carlson, J., Busse, R. T., Olson, A. E., McManus, S. M., \& Leventhal, A. (1995). Social skills assessment: A comparative evaluation of six published rating scales. School Psychology Review, 24(4), 648-671.

Diprete, T., \& Jennings, J. (2012). Social and behavioral skills and the gender gap in early educational achievement. Social Science Research, 41(1), 1-15.

Duckworth, A. L., \& Seligman, M. E. P. (2006). Self-discipline gives girls the edge: gender in self-discipline, grades, and achievement test scores. Journal of Educational Psychology, 98(1), 198-208. https://doi.org/10.1037/0022-0663.98.1.198

Durlak, J. A., Weissberg, R. P., Dymnicki, A. B., Taylor, R. D., \& Schellinger, K. B. (2011). The impact of enhancing students' social and emotional learning: A meta-analysis of school-based universal interventions. Child Development, 82(1), 405-432.

Ehrenberg, R. G., Goldhaber, D. D., \& Brewer, D. (1995). Do teachers race, gender and ethnicity matter? Evidens from the national educational longitudinal study of 1988. Industrial and Labor Relations Review, 48(3), 547-561. https://doi.org/10.1177/001979399504800312

Falch, T., \& Naper, L. R. (2013). Educational evaluation schemes and gender gaps in student achievement. Economics of Education Review, 36, 12-25. https://doi.org/10.1016/j.econedurev.2013.05.002

Frenzel, A. C., Pekrun, R., \& Goetz, T. (2007). Perceived learning environment and students' emotional experiences: A multilevel analysis of mathematics classrooms. Learning and Instruction, 17(5), 478-493. https://doi.org/10.1016/j.learninstruc.2007.09.001

Galloway, T. A., Kirkebøen, L. J., \& Rønning, M. (2011). Karakterpraksis i grunnskoler. Sammenheng mellom standpunkt-og eksamenskarakterer. [Grade practices in compulsory school. Relation between 
Gender differences in academic achievement: A matter of contextual classroom influence?

classroom grades and standardized final exam results] Retrieved from https://www.ssb.no/a/publikasjoner/pdf/rapp_201104/rapp_201104.pdf

Gamst-Klaussen, T., Rasmussen, L.-M. P., Svartdal, F., \& Strømgren, B. (2014). Comparability of the social skills improvement system to the social skills sating system: A Norwegian study. Scandinavian Journal of Educational Research, 60(1), 20-31. https://doi.org/10.1080/00313831.2014.971864

Graham, J. W. (2009). Missing data analysis: Making it work in the real world. Annual Review of Psychology, 60(1), 549-577. https://doi.org/10.1146/annurev.psych.58.110405.085530

Gresham, F. M., \& Elliott, S. N. (1990). Social skills rating system: Manual. Circle Pines,Minn.: American Guidance Service.

Gresham, F. M., \& Elliott, S. N. (2008). Social skills improvement system rating scales manual. Minneapolis: NCS Pearson.

Gresham, F. M., \& Lambros, K. M. (1998). Behavioral and functional assessment. In T. S. Watson \& F. M. Gresham (Eds.), Handbook of child behavior therapy (pp. 3-22). New York: Plenum Press.

Gresham, F. M., Elliott, S. N., Vance, M. J., \& Cook, C. R. (2011). Comparability of the social skills rating system to the social skills improvement system: Content and psychometric comparisons across elementary and secondary age levels. School Psychology Quarterly, 26(1), 27-44. https://doi.org/10.1037/a0022662

Hansen, K. (2016). The Relationship between teacher perceptions of pupil attractiveness and academic ability. British Educational Research Journal, 42(3), 376-398. https://doi.org/10.1002/berj.3227

Hattie, J. (2009). Visible learning: a synthesis of over 800 meta-analyses relating to achievement. London: Routledge.

Helbig, M. (2012). Boys do not benefit from male teachers in their reading and mathematics skills: Empirical evidence from 21 European Union and OECD Countries. British Journal of Sociology of Education(5), 661-677. https://doi.org/10.1080/01425692.2012.674782

Hendriks, A. A. J., Kuyper, H., Lubbers, M. J., \& Van der Werf, M. P. C. (2011). Personality as a moderator of context effects on academic achievement. Journal of School Psychology, 49(2), 217-248. https://doi.org/10.1016/j.jsp.2010.12.001

Hinnant, J. B., O'Brien, M., \& Ghazarian, S. R. (2009). The longitudinal relations of teacher expectations to achievement in the early school years. Journal of Educational Psychology, 101(3), 662-670. https://doi.org/10.1037/a0014306

Hinshaw, S. P. (1992). Externalizing behavior problems and academic underachievement in childhood and adolescence: Causal relationships and underlying mechanisms. Psychological Bulletin, 111(1), 127-155. https://doi.org/10.1037/0033-2909.111.1.127

Holmlund, H., \& Sund, K. (2008). Is the gender gap in school performance affected by the sex of the teacher? Labour Economics, 15(1), 37-53. https://doi.org/10.1016/j.labeco.2006.12.002

Houtte, M. V. (2004). Why boys achieve less at school than girls: the difference between boys' and girls' academic culture. Educational Studies, 30(2), 159-173. https://doi.org/10.1080/0305569032000159804

Hyde, J. S., Fennema, E., Lamon, S. J., \& Appelbaum, M. I. (1990). Gender Differences in Mathematics Performance: A Meta-Analysis. Psychological Bulletin, 107(2), 139-155. https://doi.org/10.1037/0033-2909.107.2.139

Jennings, J. L., \& DiPrete, T. A. (2010). Teacher effects on social and behavioral skills in early elementary school. Sociology of Education, 83(2), 135-159. https://doi.org/10.1177/0038040710368011

Jurado, M., Cumba-Aviles, E., Collazo, L. C., \& Matos, M. (2006). Reliability and validity of a spanish version of the social skills rating system: Teacher form. Journal of Psychoeducational Assessment, 24(3), 195-209. https://doi.org/10.1177/0734282906288961

Kaplan, A., Gheen, M., \& Midgley, C. (2002). Classroom goal structure and student disruptive behaviour. British Journal of Educational Psychology, 72(2), 191-211. https://doi.org/10.1348/000709902158847

Keith, T. (2006). Multiple regression and beyond. Boston, MA: Pearson Education.

Kikas, E., Silinskas, G., \& Soodla, P. (2015). The effects of children's reading skills and interest on teacher perceptions of children's skills and individualized support. International Journal of Behavioral 
Development, 39(5), 402-412. https://doi.org/10.1177/0165025415573641

Kjøbli, J., \& Ogden, T. (2009). Gender differences in intake characteristics and behavior change among children in families receiving parent management training. Children and Youth Services Review, 31(8), 823-830. https://doi.org/10.1016/j.childyouth.2009.03.004

Klein, J. (2004). Who is most responsible for gender differences in scholastic achievements: Pupils or teachers? Educational Research, 46(2), 183-193. https://doi.org/10.1080/0013188042000222458

Konold, T. R., Jamison, K. R., Stanton-Chapman, T. L., \& Rimm-Kaufman, S. E. (2010). Relationships among informant based measures of social skills and student achievement: A longitudinal examination of differential effects by sex. Applied Developmental Science, 14(1), 18-34. https://doi.org/10.1080/10888690903510307

Legewie, J., \& DiPrete, T. A. (2012). School context and the gender gap in educational achievement. American Sociological Review, 77(3), 463-485. https://doi.org/10.1177/0003122412440802

Lekholm, A. K., \& Cliffordson, C. (2008). Discrepancies between School Grades and Test Scores at Individual and School Level: Effects of Gender and Family Background. Educational Research and Evaluation, 14(2), 181-199. https://doi.org/10.1080/13803610801956663

Lekholm, A. K., \& Cliffordson, C. (2009). Effects of student characteristics and gender on grades in compulsory school. Educational Research and Evaluation, 15, 1-23.

Malecki, C. K., \& Elliott, S. N. (2002). Children's social behaviors as predictors of academic achievement: A longitudinal analysis. School Psychology Quarterly, 17(1), 1-23. https://doi.org/10.1521/scpq.17.1.1.19902

Manger, T., \& Gjestad, R. (1997). Gender differences in mathematical achievement related to ratio of girls to boys in school classes. International Review of Education, 43(2), 193-201. https://doi.org/10.1023/A:1002929317732

Marsh, H. W., \& Hau, K.-T. (2003). Big-Fish-Little-Pond effect on academic self-concept: A cross-cultural (26 country) test of the negative effects of academically selective schools. American Psychologist, 58(5), 364-376. https://doi.org/10.1037/0003-006X.58.5.364

Marsh, H. W., Lüdtke, O., Nagengast, B., Trautwein, U., Morin, A. J. S., Abduljabbar, A. S., \& Köller, O. (2012). Classroom climate and contextual effects: Conceptual and methodological issues in the evaluation of group-level effects. Educational Psychologist, 47(2), 106-124. https://doi.org/10.1080/00461520.2012.670488

Miles, S. B., \& Stipek, D. (2006). Contemporaneous and longitudinal associations between social behavior and literacy achievement in a sample of low-income elementary school children. Child Development, 77(1), 103-117. https://doi.org/10.1111/j.1467-8624.2006.00859.x

Moos, R. H. (1979). Evaluating educational environments. San Francisco: Jossey-Bass Publishers.

Morin, A. J. S., Marsh, H. W., Nagengast, B., \& Scalas, L. F. (2014). Doubly latent multilevel analyses of classroom climate: An illustration. Journal of Experimental Education, 82(2), 143-167. https://doi.org/10.1080/00220973.2013.769412

Murphy, J., Weil, M., \& McGreal, T. L. (1986). The basic practice model of instruction. The Elementary School Journal, 87(1), 83. https://doi.org/10.1086/461481

Neugebauer, M., Helbig, M., \& Landmann, A. (2011). Unmasking the myth of the same-sex teacher advantage. European Sociological Review, 27(5), 669-689. https://doi.org/10.1093/esr/jcq038

Nordahl, T., Egelund, N., Nordahl, S., \& Sunnevåg, A.-K. (2017). Kultur for laring Tl [Culture for learning]. Retrieved from https://www.fylkesmannen.no/PageFiles/849660/Rapport\%20for\%20Hedmarken,\%20Kultur\%20for\%2 01\%c3\%a6ring.pdf

Oberle, E., Schonert-Reichl, K. A., Hertzman, C., \& Zumbo, B. D. (2014). Social-emotional competencies make the grade: Predicting academic success in early adolescence. Journal of Applied Developmental Psychology, 35(3), 138-147. https://doi.org/10.1016/j.appdev.2014.02.004

OECD. (2015). The ABC of gender equality in education: Aptitude, behaviour, confidence, PISA. Retrieved from http://www.oecd.org/pisa/keyfindings/pisa-2012-results-gender-eng.pdf 
Gender differences in academic achievement: A matter of contextual classroom influence?

Ogden, T. (1995). Kompetanse i kontekst: en studie av risiko og kompetanse hos 10- og 13-åringer [Competence in context: A study of risk and competence in 10- and 13-year-old students] (Vol. 3). Oslo: Barnevernets utviklingssenter.

Ogden, T. (2003). The validity of teacher ratings of adolescents' social skills. Scandinavian Journal of Educational Research, 47(1), 63-76. https://doi.org/10.1080/00313830308605

Ogden, T. (2015). Sosial kompetanse og problematferd blant barn og unge [Social competence and problem behavior among children and adolescents]. Oslo: Gyldendal akademisk.

Opdenakker, M.-C., Van Damme, J., De Fraine, B., Van Landeghem, G., \& Onghena, P. (2002). The effect of schools and classes on mathematics achievement. School Effectiveness and School Improvement, 13(4), 399-427.

Patrick, H., Kaplan, A., \& Ryan, A. M. (2011). Positive classroom motivational environments. Convergence between mastery goal structure and classroom social climate. Journal of Educational Psychology, 103, 367-382.

Ready, D. D., \& Wright, D. L. (2011). Accuracy and inaccuracy in teachers' perceptions of young children's cognitive abilities: The role of child background and classroom context. American Educational Research Journal, 48 (2), 335-360.

Retelsdorf, J., Schwartz, K., \& Asbrock, F. (2014). "Michael can't read!" Teachers' gender stereotypes and boys' reading self-concept. Journal of Educational Psychology, 107(1), 186-194. https://doi.org/10.1037/a0037107

Rutter, M. (1979). Fifteen thousand hours: secondary schools and their effects on children. London: Open Books.

Schaefer, B. A., \& McDermott, P. A. (1999). Learning behavior and intelligence as explanations for children`s scholastic achievement. Journal of School Psychology, 37, 299-313.

Scheerens, J., \& Creemers, B. P. M. (1989). Conceptualizing school effectiveness. International Journal of Educational Research, 13, 691-706.

Sellström, E., \& Bremberg, S. (2006). Is there a "school effect" on pupil outcomes? A review of multilevel studies. Journal of Epidemiology and Community Health, 60(2), 149. https://doi.org/10.1136/jech.2005.036707

Snijders, T. A. B., \& Bosker, R. J. (2012). Multilevel analysis: an introduction to basic and advanced multilevel modeling. London: Sage.

Sokal, L., \& Katz, H. (2008). Effects of technology and male teachers on boys' reading. Australian Journal of Education, 52(1), 81-94. https://doi.org/10.1177/000494410805200106

Spinath, B., Eckert, C., \& Steinmayr, R. (2014). Gender differences in school success: What are the roles of students' intelligence, personality and motivation? Educational Research, 56(2), 230-243. https://doi.org/10.1080/00131881.2014.898917

Stornes, T., Bru, E., \& Idsoe, T. (2008). Classroom social structure and motivational climates: On the influence of teachers' involvement, teachers' autonomy support and regulation in relation to motivational climates in school classrooms. Scandinavian Journal of Educational Research, 52(3), 315-329. https://doi.org//10.1080/00313830802025124

Tiedemann, J. (2002). Teachers' gender stereotypes as determinants of teacher perceptions in elementary school mathematics. Educational Studies in Mathematics, 50(1), 49-62.

Topphol, A. K., Haug, P., \& Nordahl, T. (2017). SPEED-prosjektet, metode, datagrunnlag og prosedyrar [SPEED project, method, data base and procedures]. In P. Haug (Ed.), Spesialundervisning, innhald og funksjon [Special education, content and function] (pp. 31-51). Oslo: Det Norske Samlaget.

Tourangeau, K., Nord, C., Lê, T., Sorongon, A. G., \& Najarian, M. (2009). Early childhood longitudinal study, kindergarten class of 1998-99 (ECLS-K), combined user's manual for the ECLS-K eighth-grade and $K-8$ full sample data files and electronic codebooks. Retrieved from http://nces.ed.gov/ecls/data/ECLSK_K8_Manual_part1.pdf

Urdan, T. (2004). Using Multiple Methods to Assess Students' Perceptions of Classroom Goal Structures. European Psychologist, 9(4), 222-231. https://doi.org/10.1027/1016-9040.9.4.222 
Gustavsen, A. M.

Vantieghem, W., \& Van Houtte, M. (2015). Are girls more resilient to gender-conformity pressure? The association between gender-conformity pressure and academic self-efficacy. Sex Roles, 73(1-2), 1-15.

Veronneau, M.-H., \& Dishion, T. J. (2011). Middle school friendships and academic achievement in early adolescence: A longitudinal analysis. Journal of Early Adolescence, 31(1), 99-124. https://doi.org/10.1177/0272431610384485

Voyer, D., \& Voyer, S. D. (2014). Gender differences in scholastic achievement: A meta-analysis. Psychological Bulletin, 140(4), 1174-1204. https://doi.org/10.1037/a0036620

Walthall, J. C., Konold, T. R., \& Pianta, R. C. (2005). Factor structure of the social skills rating system across child gender and ethnicity. Journal of Psychoeducational Assessment, 23(3), 201-215. https://doi.org/10.1177/073428290502300301

Weis, M., Heikamp, T., \& Trommsdorff, G. (2013). Gender differences in school achievement: The role of self-regulation. Frontiers in Psychology, 4. https://doi.org/10.3389/fpsyg.2013.00442

Wentzel, K. R. (1991). Relations between social competence and academic achievement in early adolescence. Child Development, 62(5), 1066-1078.

Wentzel, K. R. (1993). Does being good make the grade? Social behavior and academic competence in middle school. Journal of Educational Psychology, 85(2), 357-364. https://doi.org/10.1037/0022-0663.85.2.357

Wentzel, K. R. (2005). Peer relationships, motivation and academic performance at school. In A. J. Elliot \& C. S. Dweck (Eds.), Handbook of competence and motivation (pp. 279-296). New York: Guildford.

Wentzel, K. R. (2015). Socialization in school settings. In J. E. Grusec \& P. D. Hastings (Eds.), Handbook of Socialization: Theory and research (2nd ed., pp. 251-275). New York: Guilford Publications.

Winters, M. A., Haight, R. C., Swaim, T. T., \& Pickering, K. A. (2013). The effect of same-gender teacher assignment on student achievement in the elementary and secondary grades: Evidence from panel data. Economics of Education Review, 34, 69-75. https://doi.org/10.1016/j.econedurev.2013.01.007

Younger, M., Warrington, M., \& Williams, J. (1999). The gender gap and classroom interactions: Reality and rhetoric? British Journal of Sociology of Education, 20, 325-341. 